\title{
Chemokines and immunity
}

\author{
Quimiocinas e imunidade
}

\author{
Diana Carolina Torres Palomino ${ }^{1,2}$, Luciana Cavalheiro Marti ${ }^{1,2}$
}

\begin{abstract}
Chemokines are a large family of small cytokines and generally have low molecular weight ranging from 7 to $15 \mathrm{kDa}$. Chemokines and their receptors are able to control the migration and residence of all immune cells. Some chemokines are considered pro-inflammatory, and their release can be induced during an immune response at a site of infection, while others are considered homeostatic and are involved in controlling of cells migration during tissue development or maintenance. The physiologic importance of this family of mediators is resulting from their specificity - members of the chemokine family induce recruitment of well-defined leukocyte subsets. There are two major chemokine sub-families based upon cysteine residues position: CXC and CC. As a general rule, members of the CXC chemokines are chemotactic for neutrophils, and CC chemokines are chemotactic for monocytes and sub-set of lymphocytes, although there are some exceptions. This review discusses the potential role of chemokines in inflammation focusing on the two best-characterized chemokines: monocyte chemoattractant protein-1, a CC chemokine, and interleukin-8, a member of the CXC chemokine sub-family.
\end{abstract}

Keywords: Chemokines/immunology; Cytokines/immunology; Immunity

\section{RESUMO}

Quimiocinas são uma grande família de pequenas citocinas e seu peso molecular varia de 7 a $15 \mathrm{kDa}$. As quimiocinas e seus receptores são capazes de controlar a migração e a residência de células imunes. Algumas quimiocinas são consideradas pró-inflamatórias e podem ser induzidas durante a resposta imune no sítio de infecção, enquanto outras são consideradas homeostáticas e estão envolvidas no controle da migração celular durante o desenvolvimento ou a manutenção dos tecidos. A importância fisiológica dessa família de mediadores é resultado de sua especificidade - os membros da família de quimiocinas induzem ao recrutamento de subtipos bem definidos de leucócitos. Existem duas grandes subfamílias de quimiocinas baseadas na posição dos resíduos de cisteínas: CXC e CC. Como regra geral, membros da família de quimiocinas CXC são quimiotáticos de neutrófilos, e as quimiocinas CC são quimiotáticos de monócitos e subtipos de linfócitos, apesar de existirem algumas exceções. Esta revisão discute o potencial papel das quimiocinas na inflamação focando nas duas quimiocinas mais bem caracterizadas: a proteína quimioatraente de monócitos-1, uma quimiocina CC, e a interleucina 8, uma quimiocina membro da subfamília CXC.

Descritores: Quimiocinas/imunologia; Citocinas/imunologia; Imunidade

\section{INTRODUCTION}

Chemokines constitute a large family of small cytokines and generally have low molecular weight ranging from 7 to $15 \mathrm{kDa}$. Chemokines and their receptors are able to control the migration and residence of all immune cells. Some chemokines are considered pro-inflammatory and their release can be induced during an immune response at a site of infection, while others are considered homeostatic, and are involved in the control of cells migration during tissue development or maintenance. The physiologic importance of this family of mediators is resulting from their specificity; members of the chemokine family induce recruitment of well-defined leukocyte subsets. ${ }^{(1,2)}$

Many chemokines were initially identified by subtraction hybridization as an immediate or early response genes induced by growth factors. Based on this property, it was supposed that chemokines were involved in cellular proliferation and acted as nuclear factors. However, when complete amino acid sequences were deduced, it was clear that chemokines were secretory proteins.

There are two families of chemokines based on the first cysteine residue: the family called CC chemokines (Chart 1), also known as beta-chemokines. The genes encoding the CC chemokines are located on chromosome 17. CC chemokines stimulate mainly monocytes, but also basophils, eosinophils,

\footnotetext{
'Hospital Israelita Albert Einstein, São Paulo, SP, Brazil.

${ }^{2}$ Allergy and Immunopathology Graduate Program of Faculdade de Medicina, Universidade de São Paulo, São Paulo, SP, Brazil.

Corresponding author: Luciana Cavalheiro Marti - Avenida Albert Einstein, 627/701 - Morumbi - Zip code: 05652-900 - São Paulo, SP, Brazil - Phone: (55 11) 2151-1353 - E-mail: Imarti@einstein.br

Received on: July 20, 2015 - Accepted on: Aug 18, 2015
}

DOI: 10.1590/S1679-45082015RB3438 
T-lymphocytes, and natural killer (NK) cells. The other family CXC (Chart 2), known as alpha-chemokines, have an intervening amino acid between the first two cysteines and are located in the chromosome $4 .^{(3-5)}$ These chemokines, which mainly stimulate neutrophil chemotaxis, contain a Glu-Leu-Arg (ELR) sequence in the $\mathrm{N}$-terminus that is essential for receptor binding. ${ }^{(6,7)}$

Chart 1. Chemokines: $\mathrm{CC}$, receptors and immune function

\begin{tabular}{|c|c|c|c|}
\hline Chemokine & $\begin{array}{c}\text { Other } \\
\text { names }\end{array}$ & Receptor & Immune function \\
\hline CCL1 & $1-309$ & CCR8 & Th2 and Treg trafficking \\
\hline CCL2 & MCP-1 & CCR2 & Monocyte trafficking \\
\hline CCL3 & MIP-1 $\alpha$ & CCR1, CCR5 & $\begin{array}{l}\text { Macrophage-NK migration; } \\
\text { T cell/DC interaction }\end{array}$ \\
\hline CCL4 & MIP-1 $1 \beta$ & CCR5 & $\begin{array}{l}\text { Macrophage-NK migration; } \\
\text { T cell/DC interaction }\end{array}$ \\
\hline CCL5 & RANTES & CCR1, CCR3, CCR5 & $\begin{array}{l}\text { Macrophage-NK migration; } \\
\text { T cell/DC interaction }\end{array}$ \\
\hline CCL6 & C-10 & Unknown & $?$ \\
\hline CCL7 & MCP-3 & CCR2, CCR3 & Monocyte mobilization \\
\hline CCL8 & MCP-2 & $\begin{array}{c}\text { CCR1, CCR2, CCR3, } \\
\text { CCR5 }\end{array}$ & Th2 response \\
\hline CCL9 & MIP-1 $\gamma$ & Unknown & $?$ \\
\hline CCL10 & MIP-1 $\gamma$ & Unknown & $?$ \\
\hline CCL11 & Eotaxin & CCR3 & $\begin{array}{l}\text { Eosinophil and basophil } \\
\text { migration }\end{array}$ \\
\hline CCL12 & MCP-5 & CCR2 & Monocyte trafficking \\
\hline CCL13 & MCP-4 & CCR2, CCR3, CCR5 & Th2 response \\
\hline CCL14 & HCC-1 & CCR1 & $?$ \\
\hline CCL15 & HCC-2 & CCR1, CCR3 & $?$ \\
\hline CCL16 & HCC-4 & CCR1, CCR2, CCR5 & $?$ \\
\hline CCL17 & TARC & CCR4 & $\begin{array}{l}\text { Th2 response, Th2 cell migration, } \\
\text { Treg, lung and skin homing }\end{array}$ \\
\hline CCL18 & PARC & CCR8 & $\begin{array}{c}\text { Th2 response, marker AAM, } \\
\text { skin homing }\end{array}$ \\
\hline CCL19 & MIP-3及 & CCR7 & $\begin{array}{l}\text { T cell and } \mathrm{DC} \text { homing to } \\
\text { lymph node }\end{array}$ \\
\hline CCL2O & MIP-3 $\alpha$ & CCR6 & $\begin{array}{l}\text { Th17 response, B cell and } \\
\text { DC homing to gut associated } \\
\text { lymphoid tissue }\end{array}$ \\
\hline CCL21 & SLC & CCR6, CCR7 & $\begin{array}{l}\text { T cell and DC homing to } \\
\text { lymph node }\end{array}$ \\
\hline CCL22 & MDC & CCR4 & $\begin{array}{c}\text { Th2 response, Th2 cell migration, } \\
\text { T reg migration }\end{array}$ \\
\hline CCL23 & MIP-3 & Unknown & $?$ \\
\hline CCL24 & Eotaxin-2 & CCR3 & $\begin{array}{c}\text { Eosinophil and basophil } \\
\text { migration }\end{array}$ \\
\hline CCL25 & TECK & CCR9 & $\begin{array}{l}\text { T cell homing to gut, } \\
\text { thymocyte migration }\end{array}$ \\
\hline CCL26 & Eotaxin-3 & CCR3, CX3CR1 & $\begin{array}{l}\text { Eosinophil and basophil } \\
\text { migration }\end{array}$ \\
\hline CCL27 & CTAK & CCR10 & T cell homing to skin \\
\hline CLL28 & MEC & CCR3, CCR10 & $\begin{array}{l}\text { T cell and IgA plasma cell } \\
\text { homing to mucosa }\end{array}$ \\
\hline
\end{tabular}

Source: Murphy PM et al.(3)
Chart 2. Chemokines: $\mathrm{CXC}$, receptors and immune function

\begin{tabular}{|c|c|c|c|}
\hline Chemokine & $\begin{array}{l}\text { Other } \\
\text { names }\end{array}$ & Receptor & Immune function \\
\hline CXCL1 & $\mathrm{GRO} \alpha$ & CXCR2 & Neutrophil trafficking \\
\hline CXCL2 & GRO $\beta$ & CXCR2 & Neutrophil trafficking \\
\hline CXCL3 & $\mathrm{GRO} \gamma$ & CXCR2 & Neutrophil trafficking \\
\hline CXCL4 & PF4 & $?$ & Pro-coagulant \\
\hline CXCL5 & ENA78 & CXCR2 & Neutrophil trafficking \\
\hline CXCL6 & GCP-2 & CXCR1, CXCR2 & Neutrophil trafficking \\
\hline CXCL7 & NAP-2 & CXCR2 & Neutrophil trafficking \\
\hline CXCL8 & IL-8 & CXCR1, CXCR2 & Neutrophil trafficking \\
\hline CXCL9 & MIG & CXCR3 & $\begin{array}{c}\text { Th1 response, Th1, CD8 and } \\
\text { NK trafficking }\end{array}$ \\
\hline CXCL10 & IP-10 & CXCR3 & $\begin{array}{c}\text { Th1 response, Th1, CD8 and } \\
\text { NK trafficking }\end{array}$ \\
\hline CXCL11 & I-TAC & CXCR3 & $\begin{array}{c}\text { Th1 response, Th1, CD8 and } \\
\text { NK trafficking }\end{array}$ \\
\hline CXCL12 & SDF-1 & CXCR4 & Bone marrow homing \\
\hline CXCL13 & $B L C$ & CXCR5 & $\begin{array}{l}\text { B cell and Tfh positioning in } \\
\text { lymph node }\end{array}$ \\
\hline CXCL14 & BRAK & $?$ & Macrophage skin homing \\
\hline CXCL15 & Lungkine & $?$ & $?$ \\
\hline CXCL16 & 5R-PSOX & CXCR6 & NKT and ILC migration and survival \\
\hline CXCL17 & $\mathrm{DMC}$ & $?$ & $?$ \\
\hline XCL1 & SCM-1 $\alpha$ & XCR1 & Cross-presentation by CD8+ DC \\
\hline XCL2 & SCM-1 $\beta$ & XCR2 & Cross-presentation by CD8+ DC \\
\hline CX3CL1 & Fractalkine & CX3CR1 & NK, monocyte and T cell migration \\
\hline
\end{tabular}

Chemokine receptors are differentially expressed by all leukocytes and can be divided into two groups: $G$ protein-coupled chemokine receptors, which is activated by pertussis toxin (PTX)-sentive $\mathrm{G}_{\mathrm{i}}$-type $\mathrm{G}$ protein; and an atypical chemokine receptors, which appear to form chemokine gradients and dampen inflammation by scavenging chemokines in a $\mathrm{G}$ protein independent manner. ${ }^{(8)}$

Nowadays approximately 50 endogenous chemokines ligands and 20 G-protein-coupled receptors have been described. However, there is still a lot to be comprehended in this field, particularly regarding mechanisms during diseases development. In this review, we focused on a timeline basic knowledge in chemokines.

\section{MONOCYTE CHEMOATTRACTANT PROTEIN-1 (CCL2/MCP-1) AND CC CHEMOKINES}

Acute inflammation is a complex process characterized by the coordinated migration of effector cells to the site of inflammation, as well as displacement of immune cells from peripheral sites to draining lymphoid organs to initiate immune response. Such coordinated movement 
of cells requires the induced expression of inflammatory chemokines and their respective receptors on target cells. The interaction between chemoattractant and immune cells trigger a series of biochemical and cellular coordinate events. ${ }^{(8,9)}$

CCL2 is typically secreted in two predominant forms with similar molecular weights of 9 and $13 \mathrm{kDa}$. They have the same protein core and differ by the addition of O-linked carbohydrates to the larger form. ${ }^{(10)}$ Despite this difference, they have identical activities in vitro. ${ }^{(11)}$

CCL2 stimulates chemotaxis of monocytes and several cellular events associated with chemotaxis, including $\mathrm{Ca}^{2+}$ flux and integrin expression. It is also a weak inducer of cytokine expression in monocytes and, at high concentrations, elicits a respiratory burst leading to generation of reactive oxygen species. ${ }^{(11,12)}$

Monocytes utilize different chemoattractant molecules to migrate; however, CCL2 and CCL7 are rapidly produced by stromal cells and immune cells after pattern-recognition receptors (PRR) activation or after cytokine stimulation. CCL2 dimerizes and binds to extracellular matrix glycosaminoglycans, thus establishing a stable gradient for CCR2+ inflammatory monocytes. ${ }^{(8,13)}$

CCL2 expression has been identified upregulated in certain cell types of some diseases, such as macrophages/ foam cells and smooth muscle cells in atherosclerosis; delayed-type of hypersensitivity reactions in the skin mononuclear phagocytes, endothelial cells, and keratinocytes; melanoma cells in skin cancer and synoviocites of rheumatoid arthritis..$^{(14-17)}$

Two other chemokines structurally related to CCL2 are named CCL8 (MCP-2) and CCL7 (MCP-3). Generally, CCL2 and CCL7 have similar properties, although CCL7 may exhibit characteristics from both CCL2 and CCL5 (RANTES), suggesting that it has a broader range of chemokine binding. Others $\mathrm{CC}$ chemokines include macrophage inflammatory protein $1 \alpha$ (MIP-1 $\alpha /$ CCL3), macrophage inflammatory protein$1 \beta$ (MIP-1ß/CCL4), T-cell activation gene-3 (TCA-3/ CCL1), and CCL5, which support and regulate activated T-cells. ${ }^{(12,18,19)}$

Eosinophil is a leukocyte present in high numbers during inflammatory allergic reactions, such as asthma and rhinitis; there is evidence that links accumulation and activation of these cells with tissue injury and lung dysfunction. ${ }^{(20-22)}$ Humbles et al. purified and sequenced a CC-chemokine from bronchoalveolar lavage fluid of allergen-challenged sensitized animal model. They also identified CCL11 (Eotaxin-1) as a local chemoattractant responsible for eosinophil recruitment, via CCR3, a chemokine receptor highly expressed on eosinophils. ${ }^{(23)}$
These leukocytes express CCR 1 and CCR 3 and can respond to a variety of chemokines including CCL11, CCL24 (Eotaxin-2) and CCL26 (Eotaxin-3). ${ }^{(24,25)}$

CCL19 (MIP-3 3 ) and CCL21 (SLC) are expressed mainly by stromal cells in $\mathrm{T}$ cell-rich zones of lymph nodes. They are mediators of homeostatic trafficking of naïve $\mathrm{T}$ cells, but also play a role on $\mathrm{T}$ cell priming and activation, as well as on lymphocytes recruitment to inflamed tissue. The pathway signaling of both proteins take place via CCR7, which is expressed on T cells and mature dendritic cells. Although CCL19 and CCL21 exhibit the same affinity for CCR7, only CCL19 has ability to desensitize and internalize the receptor. ${ }^{(8)}$

$\mathrm{T}$ cells and progenitor cells enter the thymus in response to CCL21/SLC and CCL25/TECK, which are produced by thymic epithelium and surrounding structures. CCR9 guides these cells to the subcapsular zone. Subsequent thymic maturation from doublepositive through single-positive thymocytes occurs in concert with their migration into the medulla, which is dependent on CCR7 and perhaps another chemokine yet to be defined. ${ }^{(26)}$

In general, chemokines CCL2, CCL3, CCL4, CCL5, CCL11 and CCL13 are classified as inflammatory; CCL18, CCL19, CCL21, CCL25 and CCL27 as homeostatic. CCL1, CCL17, CCL20 and CCL22 with dual function inflammatory and homeostatic while CCL14, CCL15, CCL16 and CCL23 are related with plasma or platelet. ${ }^{(27)}$

\section{INTERLEUKIN-8 AND CXC CHEMOKINES}

lnterleukin-8 (IL-8/CXCL8) is a prototypical member of CXC chemokine family. The IL- 8 gene encodes a 99-aminoacid translation product. It undergoes proteolytic cleavage of the amino terminal yielding several different products. IL-8 in solution is thought to exist as non-covalently linked dimer, and, in vitro, it is a potent chemoattractant for neutrophils. It has been reported to be also a chemoattractant for a subset of T-lymphocytes. ${ }^{(28)}$

IL-8 has also been named neutrophil activating protein-1 (NAP-1), since it stimulates release of neutrophil granules. Like many other chemoattractants, IL-8 induces re-arrangement of cytoskeleton, changes in intracellular $\mathrm{Ca}^{2+}$ levels, activation of integrins, exocytosis of granule proteins, and respiratory burst. ${ }^{(29)}$ There are some chronic inflammatory diseases, such as psoriasis, rheumatoid arthritis, as well as pulmonary diseases, in which IL-8 is overexpressed, and high levels of IL-8 are also seen after septic shock or systemic administration of endotoxin. ${ }^{(30-32)}$ 
Regarding other CXC-chemokines members, neutrophils are the main responsive cell type, since they express receptors CXCR1 and CXCR2, which are able to bind to CXCL1, CXCL2, CXCL5, CXCL6, CXCL7 and CXCL8. In acute inflammation initiated by bacterial invasion, neutrophils are the first cells that infiltrate into the tissue. Neutrophils play a critical role during infection control, first by their capacity of microorganism phagocytosis, and second by releasing other chemotactic mediators, such as CXCL1, CXCL8, CXCL9 and CXCL10 that recruit other leucocytes to the affected tissues. ${ }^{(33)}$

Chemokines control innate immune cell trafficking between the bone marrow, blood, and peripheral tissues during inflammation. At the same time, systemic levels of G-CSF lead to a reduction on CXCL12 production by bone marrow and decreased CXCR 4 expression by neutrophils. Release of neutrophil from bone marrow into the blood is triggered by the switch of activated receptor, from $\mathrm{CXCR} 4$ to $\mathrm{CXCR} 2 .{ }^{(8)}$

Mast cells also play an important role in acute inflammation because they express a wide variety of PRR and contain large granules of preformed inflammatory mediators. LPS stimulated murine peritoneal mast cells leads to immediate release of CXCL1- and CXCL2containing granules, but not histamine-containing granules, as well as transcriptional activation of CXCL1 and CXCL2. This promotes early neutrophil recruitment that is abolished in mast cell-depleted mice, but not macrophage-depleted mice. ${ }^{(8)}$

CX3CL1 (or fractalkine) is an atypical chemokine with a documented role in the development of numerous inflammatory diseases, including atherosclerosis. It represents the only known member of the CX3C family and was first characterized by Bazan et al. ${ }^{(34)}$ It is a unique chemotactic factor existing in both membranebound and soluble form. The human CX3CL1 molecule consists of 373 amino acids and it is functionally divided into four domains: an extracellular domain of 76 amino acids connected to an extended 241 amino acid mucinlike stalk, followed by transmembrane and intracellular domains of 21 and 35 amino acids, respectively. CX3CL1 is synthesized as a membrane-bound molecule with the chemokine domain presented on a mucin-like stalk, which mediates the direct capture of circulating leukocytes. Cleavage at the base of this stalk by a protease, namely the tumor necrosis alpha-converting enzyme, generates a soluble chemokine, which function as a potent chemoattractant of target cells. ${ }^{(34,35)}$

The fractalkine receptor CX3CR1 is a well-established marker of anti-inflammatory or patrolling monocytes known by providing pro-survival signal to anti- inflammatory monocytes, but is also present in NK cells, $\mathrm{T}$ cells, and smooth muscle cells, where it mediates migration, adhesion and proliferation. CXCR3 is also present on pro-inflammatory monocytes and may play a role on normal function of inflammatory monocytes. ${ }^{(8)}$

In general, chemokines CXCL1, CXCL2, CXCL3, CXCL5, CXCL6, CXCL7 and CXCL8 are classified as inflammatory; CXCL12 and CXCL13 as homeostatic. CXCL9, CXCL10, CXCL11 and CXCL16 with dual function inflammatory and homeostatic, while CXCL4 is plasmatic or platelet related. ${ }^{(27)}$

\section{ACKNOWLEDGMENTS}

We are grateful to Fundação de Amparo à Pesquisa do Estado de São Paulo (FAPESP) grant number 2014/15504-7 and to Sociedade Beneficente Israelita Brasileira Hospital Albert Einstein for their support.

\section{REFERENCES}

1. Oppenheim JJ, Zachariae CO, Mukaida N, Matsushima K. Properties of the novel proinflammatory supergene "intercrine" cytokine family. Annu Rev Immunol. 1991;9:617-48. Review.

2. Raz $\mathrm{E}$, Mahabaleshwar $\mathrm{H}$. Chemokine signaling in embryonic cell migration: a fisheye view. Development. 2009;136(8):1223-9. Review.

3. Murphy PM, Baggiolini M, Charo IF, Hébert CA, Horuk R, Matsushima K, et al. International union of pharmacology. XXII. Nomenclature for chemokine receptors. Pharmacol Rev. 2000;52(1):145-76. Review.

4. Luster $A D$, Ravetch JV. Genomic characterization of a gamma-interferoninducible gene (IP-10) and identification of an interferon-inducible hypersensitive site. Mol Cell Biol. 1987:7(10):3723-31.

5. Mukaida N, Shiroo M, Matsushima K. Genomic structure of the human monocyte-derived neutrophil chemotactic factor IL-8. J Immunol. 1989;143(4): 1366-71.

6. Clark-Lewis I, Schumacher C, Baggiolini M, Moser B. Structure-activity relationships of interleukin-8 determined using chemically synthesized analogs. Critical role of $\mathrm{NH} 2$-terminal residues and evidence for uncoupling of neutrophil chemotaxis, exocytosis, and receptor binding activities. J Biol Chem. 1991;266(34): 23128-34.

7. Hébert CA, Vitangcol RV, Baker JB. Scanning mutagenesis of interleukin-8 identifies a cluster of residues required for receptor binding. J Biol Chem. 1991;266(28):18989-94.

8. Griffith JW, Sokol CL, Luster AD. Chemokines and chemokine receptors: positioning cells for host defense and immunity. Annu Rev Immunol. 2014; 32:659-702. Review.

9. Murdoch C, Finn A. Chemokine receptors and their role in inflammation and infectious diseases. Blood. 2000;95(10):3032-43. Review

10. Jiang Y, Valente AJ, Williamson MJ, Zhang L, Graves DT. Post-translationa modification of a monocyte-specific chemoattractant synthesized by glioma, osteosarcoma, and ascular smooth muscle cells. J Biol Chem. 1990;265(30): 18318-21.

11. Jiang Y, Beller DI, Frendl G, Graves DT. Monocyte chemoattractant protein-1 regulates adhesion molecule expression and cytokine production in human monocytes. J Immunol. 1992;148(8):2423-8.

12. Rollins BJ, Morrison ED, Stiles CD. Cloning and expression of JE, a gene inducible by platelet-derived growth factor and whose product has cytokinelike properties. Proc Natl Acad Sci USA. 1988;85(11):3738-42. 
13. Proudfoot AE, Handel TM, Johnson Z, Lau EK, LiWang P, Clark-Lewis I, et al. Glycosaminoglycan binding and oligomerization are essential for the in vivo activity of certain chemokines. Proc Natl Acad Sci USA. 2003;100(4):1885-90.

14. Ylä-Herttuala S, Lipton BA, Rosenfeld ME, Särkioja T, Yoshimura T, Leonard EJ, et al. Expression of monocyte chemoattractant protein 1 in macrophage-rich areas of human and rabbit atherosclerotic lesions. Proc Natl Acad Sci USA. 1991;88(12):5252-6.

15. Graves DT, Barnhill R, Galanopoulos T, Antoniades HN. Expression of monocyte chemotactic protein-1 in human melanoma in vivo. Am J Pathol. 1992;140(1):9-14.

16. Villiger PM, Terkeltaub R, Lotz M. Production of monocyte chemoattractant protein-1 by inflamed synovial tissue and cultured synoviocytes. J Immunol. 1992;149(2):722-7.

17. Yu X, Barnhill RL, Graves DT. Expression of monocyte chemoattractant protein-1 in delayed type hypersensitivity reactions in the skin. Lab Invest. 1994;71(2):226-35.

18. Opdenakker G, Froyen G, Fiten P, Proost P, Van Damme J. Human monocyte chemotactic protein-3 (MCP-3): molecular cloning of the CDNA and comparison with other chemokines. Biochem Biophys Res Commun. 1993;191 (2):535-42.

19. Broxmeyer HE, Sherry B, Lu L, Cooper S, Carow C, Wolpe SD, et al. Myelopoietic enhancing effects of murine macrophage inflammatory proteins 1 and 2 on colony formation in vitro by murine and human bone marrow granulocyte/ macrophage progenitor cells. J Exp Med. 1989;170(5):1583-94.

20. De Monchy JG, Kauffman HF, Venge P, Koëter GH, Jansen HM, Sluiter HJ, et al. Bronchoalveolar eosinophilia during allergen-induced late asthmatic reactions. Am Rev Respir Dis. 1985;131(3):373-6.

21. Bousquet J, Chanez P, Lacoste JY, Barnéon G, Ghavanian N, Enander I, et al. Eosinophilic inflammation in asthma. N Engl J Med. 1990;323(15):1033-9.

22. Bradley BL, Azzawi M, Jacobson M, Assoufi B, Collins JV, Irani AM, et al. Eosinophils, T-lymphocytes, mast cells, neutrophils, and macrophages in bronchial biopsy specimens from atopic subjects with asthma: comparison with biopsy specimens from atopic subjects without asthma and normal control subjects and relationship to bronchial hyperresponsiveness. J Allergy Clin Immunol. 1991;88(4):661-74.

23. Humbles AA, Conroy DM, Marleau S, Rankin SM, Palframan RT, Proudfoot $A E$, et al. Kinetics of eotaxin generation and its relationship to eosinophil accumulation in allergic airways disease: analysis in a guinea pig model in vivo. J Exp Med. 1997;186(4):601-12.
24. Kalomenidis I, Stathopoulos GT, Barnette R, Guo Y, Peebles RS, Blackwell TS, et al. Eotaxin-3 and interleukin-5 pleural fluid levels are associated with pleural fluid eosinophilia in post-coronary artery bypass grafting pleural effusions. Chest. 2005;127(6):2094-100.

25. Pope SM, Zimmermann N, Stringer KF, Karow ML, Rothenberg ME. The eotaxin chemokines and CCR3 are fundamental regulators of allergen-induced pulmonary eosinophilia. J Immunol. 2005;175(8):5341-50.

26. Love PE, Bhandoola A. Signal integration and crosstalk during thymocyte migration and emigration. Nat Rev Immunol. 2011;11(7):469-77. Review.

27. Le Y, Zhou Y, Iribarren P, Wang J. Chemokines and chemokine receptors: their manifold roles in homeostasis and disease. Cell Mol Immunol. 2004;1(2):95-104. Review.

28. Huber AR, Kunkel SL, Todd RF 3rd, Weiss SJ. Regulation of transendothelial neutrophil migration by endogenous interleukin-8. Science. 1991;254(5028): 99-102. Erratum in: Science. 1991;254(5032):631. Science. 1991;254(5037): 1435.

29. Paccaud JP, Schifferli JA, Baggiolini M. NAP-1/L-8 induces up-regulation of CR1 receptors in human neutrophil leukocytes. Biochem Biophys Res Commun. 1990;166(1):187-92.

30. Camp R, Bacon K, Fincham N, Mistry K, Ross J, Lawlor F, et al. Chemotactic cytokines in inflammatory skin disease. Adv Exp Med Biol. 1991;305:109-18. Review.

31. Kunkel SL, Standiford T, Kasahara K, Strieter RM. Interleukin-8 (IL-8): the major neutrophil chemotactic factor in the lung. Exp Lung Res. 1991;17(1):17-23.

32. Martich GD, Danner RL, Ceska M, Suffredini AF. Detection of interleukin 8 and tumor necrosis factor in normal humans after intravenous endotoxin: the effect of antiinflammatory agents. J Exp Med. 1991;173(4):1021-4.

33. De Filippo K, Dudeck A, Hasenberg M, Nye E, van Rooijen N, Hartmann K, et al. Mast cell and macrophage chemokines CXCL1/CXCL2 control the early stage of neutrophil recruitment during tissue inflammation. Blood. 2013; 121(24):4930-7.

34. Bazan JF, Bacon KB, Hardiman G, Wang W, Soo K, Rossi D, et al. A new class of membrane-bound chemokine with a CX3C motif. Nature. 1997; 385(6617):640-4.

35. Apostolakis S, Spandidos D. Chemokines and atherosclerosis: focus on the CX3CL1/CX3CR1 pathway. Acta Pharmacol Sin. 2013;34(10):1251-6. Review. 